\title{
Secteur 5 : région du Saulnois
}

René Berton

URL : http://journals.openedition.org/adlfi/8754

ISSN : 2114-0502

Éditeur

Ministère de la culture

Référence électronique

René Berton, «Secteur 5 : région du Saulnois », ADLFI. Archéologie de la France - Informations [En ligne], Lorraine, mis en ligne le 01 mars 2001, consulté le 03 mai 2019. URL : http://journals.openedition.org/ adlfi/8754

Ce document a été généré automatiquement le 3 mai 2019.

(c) Ministère de la Culture et de la Communication, CNRS 


\title{
Secteur 5 : région du Saulnois
}

\author{
René Berton
}

Identifiant de l'opération archéologique : F1354200100071

Date de l'opération : 2001 (PA)

1 RÉCHICOURT-LA-PETITE (54), Haut d'Eau

2 Des amas de fosses oblongues, de dimensions semblables, laissent supposer des inhumations.

3 LOISY (54), En Notrée

4 Lors de la campagne de prospection aérienne de 1998, seul le tracé linéaire était apparu. En 2001, dans les zones d'érosion, apparaissent des fosses.

5 DONJEUX (57), Les Petits Sillons

6 Petit bâtiment rural découvert en prospection au sol en 1995 et dont le plan s'est révélé à la photographie aérienne en 2001.

7 (Fig. $\mathrm{n}^{\circ} 1$ : Loisy, En Notrée - Fosses)

8 BERTON René

\section{ANNEXES}


Fig. $\mathrm{n}^{\circ} 1$ : Loisy, En Notrée - Fosses

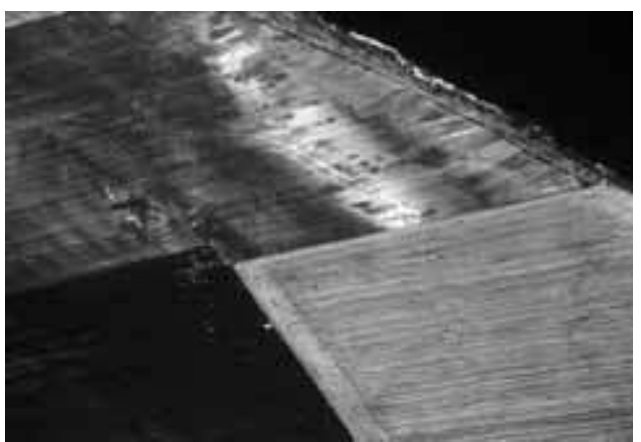

Auteur(s) : Berton, René. Crédits : Berton René (2001)

INDEX

Index géographique : Lorraine

Thèmes : érosion, fosse, habitat rural, inhumation operation Prospection aérienne (PA)

\section{AUTEURS}

RENÉ BERTON 